\title{
Bureaucratic Representation In Duality Structure: Beyond Positivism Epistemology In Understanding Bureaucracy
}

\author{
Laurensius Petrus Sayrani \\ Nusa Cendana University, Kupang, Indonesia \\ laurensayrani@yahoo.co.id
}

\begin{abstract}
Abtract. The process and dynamics in the bureaucracy is not only about a single process (managerial mechanistic, hierarchical, formalistic) however, actually it is a dynamic arena as shown in the phenomenon of representational bureaucratic practice. The practice of representational bureaucracy which is coinciding in the formal process of bureaucracy based on meritocracy is the evidence that bureaucracy's dynamics in the duality's structures that bring together simultaneously between formal and informal mechanisms. This is dismisses the paradigm of structural dualism which carried the mainstream theory of bureaucracy theory currently, which is subjective including the problem of inter-group relations (ethnic and religious) must be removed from the bureaucracy because it is considered irrational. The practice of representation in the bureaucracy, especially the informal mechanisms which developed in the bureaucracy has shows that the bureaucracy can not be studied with dualism structures's frame of mind that sees the formal structure of bureaucracy with bureaucratic behavior and also at the other levels that is between political actors (heads of regions) and dichotomous bureaucratic actors (separated/one-way determination). In contrast, the practice of representation in the bureaucracy shows that the bureaucracy actually works/proceed in the framework of the duality's structure. In duality's structure, the frame of the bureaucratic structure and political actors behavior and bureaucracy (agency) always interact dynamically and reciprocally (two-way). On the one hand, the bureaucratic structure will determine political actors behavior and bureaucracy through an objectifying process that produces a formal bureaucratic system. On the other hand, political actors and bureaucracy have the capacity to recreate bureaucracy through a subjective process that produce an informal system in the bureaucracy. The practice of representational bureaucracy in this duality's structure is only possible to understand if bureaucracy is understood or studied through a non positivistic epistemology that allows reality to be studied or understood as a non-singular subjective reality and be formed by an intersubjective relation in the bureaucracy.
\end{abstract}

Keywords: Bureaucratic Representation, Duality Structure, Non-Positivistic Epistemology

\section{Introduction}

The study of representational bureaucracy in Indonesia is not sufficiently developed despite in the theoretical discourse of democratic administration, this study has expanded scope of the debate on essence and the study of administration. The literature and study of the dimensions of plurality in the context of democratization (Justice's Dimension) which must be responded by bureaucracy are not available and still dominated by political studies with a focus on politics' identity. Publication of the study among other things conducted by Sjaf 
(2014) which examines ethnic politics in Kendari. As well as being done by Yakoop (2013) on ethnicity as a security instrument in West Kalimantan also by Buchari (2014) which also examines ethnic awakening to identity politics in the same area.

In contrast to the growing political identity perspective in studying the reality of ethnic and religious identities within the bureaucracy in Indonesia which tend to be positivistic by putting this issue as pathological in the bureaucracy, then differently, the representational perspective seeks to understand it (the reality of ethnic and religious identities) in the bureaucracy as an inevitable reality that must be managed with the right approach.

The novelty of this article's review is in the use of a representational approach in studying the reality of diversity associated with bureaucracy. Through this approach, the reality of diversity in the bureaucracy that has been considered pathological as the implication of using the approach of political identity studies (political studies) and meritocracy (bureaucratic study) as mainstream study, can be understood differently based on different contexts (locality). The sociological needs of managing bureaucracy at the local level with plural society may be more adequately explained.

Although the study of bureaucracy using representative perspectives has not been sufficiently developed in Indonesia, but in some countries shows the opposite. Studies on issues of race identity, gender, social class in the bureaucracy using representative perspectives are quite developed in America, Korea and Malaysia respectively.

There are several studies on representational bureaucracy in the form of dissertations at various universities, especially in the United States; Lewis (1988), Kim (1990), Selden (1995), Goode (2000), Mohamed (2004), Ballard (2015) and Clark (2015) which generally focus on two main approaches: 1) description of representation level of a group (ethnic, racial and gender) in bureaucracy structure (passive / descriptive representation), 2) on the activity of a group (ethnicity, race and gender) in fighting for the issue of his group in bureaucratic policy (active representation / substance) along with the factors which influence it's connection.

To complement the various studies of the existing representational bureaucracy, this article tries to contribute to the explanation of representational bureaucratic practices related to social, cultural and political characteristics, especially in the territory (country) which is in the process of consolidating democracy like Indonesia. Therefore, the study in this article uses a different path (approach) that is the construction approach in understanding the process of forming (dynamics) representation in the bureaucracy. It means, representational bureaucracy is understood as a process of formation (construction) associated with certain contexts and the diverse interests of various actors both bureaucracy and politics.

This article would like to show how the workings of informal mechanisms in formal bureaucracy in the case of formation of representational practices in East Nusa Tenggara (NTT) as an approach of political actors and bureaucracy at the local level to meet their interests, especially in the context of diverse society. In order to understand this phenomenon adequately, the choice of epistemology based on non-positivistic becomes a necessity.

Positivistic paradigm that became mainstream in the study of bureaucracy, especially in Indonesia, led to the study of bureaucracy tends to be stagnant (not dynamic), especially faced with a complex situation that is the condition of diverse society. Bureaucratic studies tend to ignore this reality and are used as a symptom of pathology for bureaucracy. The 
implication is the bureaucracy fails to explain (understand) impasses of formal bureaucratic practices which are tend to fail such as the bureaucratic reform program. In this situation, public administration scientists seem to remain faithful in searching for the source of such failure to the institutional dimension (formal) by conducting a variety of deterministic organizational engineering.

\section{Literature Review}

There are important issues that tend to stutter facing by the theory of public administration, especially based on the positivistic paradigm of justice in a diverse society. Positivistic paradigms based on efficiency values tend not to take different accessibility in diverse groups of people into account. As Frederickson (2003) argues that there is a tendency in public administration to make assumptions that every citizen is equal and receives service in equal measure and thus tends to ignore unequal realities that harm minority group (marginal) groups. This situation has resulted in a situation of injustice in the achieved efficiency regime (Maroney and Wiliams, 2007, Alkadry, 2007). Therefore, this study is fundamentally related to the question of how the reality of plurality and relation between social identity (ethnicity, religion, gender, social class, etc.) is managed mainly by state institutions including bureaucracy?

Furthermore, as stated (Hamilton, 2003), the study of public administration cannot be separated from the accusation to produce new values that can overcome the problems of social plurality reality and its problems ethically, politically (policy) and management. This discourse can be achieved when to understand the democratic bureaucracy in which there is a serious effort to balance between equality with hierarchy, public participation with expert participation, equity with efficiency. In this kind of discourse exactly, representational bureaucracy is a substantial idea for producing ways of thinking and working in the public administration to be more responsive, participatory in policy-making, social justice and more adequately accountability (Alkadry, 2007; Major, 2011). 
Picture 1

Representative Bureucracy as Relation Mediation of Bureucracy and Democracy

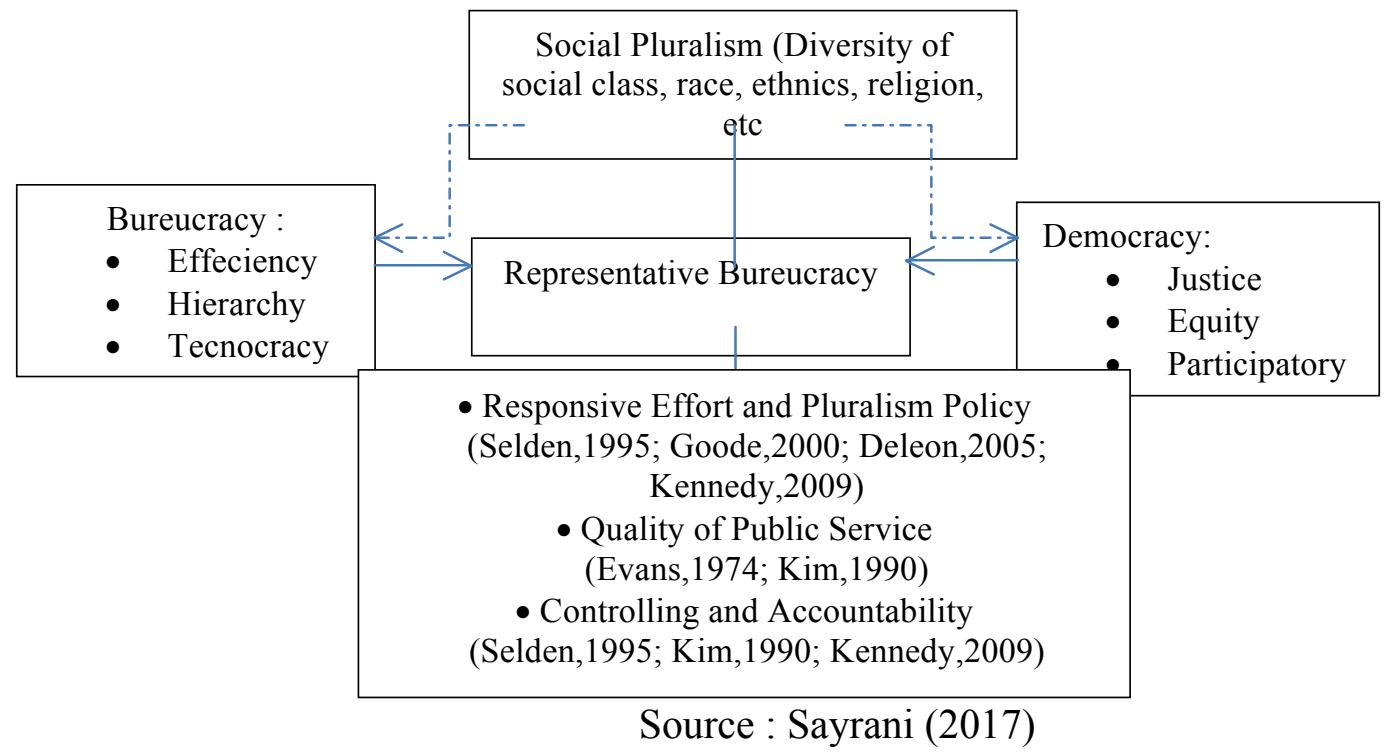

This picture shows that the representation of public plurality by bureaucracy is important because bureaucracy will become more responsive organization to the diverse needs of different groups in policy-making (Goode, 2000; Kennedy, 2009). Public services provided by the bureaucracy are also believed to be better because through the representation of possible maximum service to different segments of society (Evans, 1974). This is based on the assumption that Crotty and Crotty (2009) asserted that identity, social attribute, and social background are something that not disappearing when a person (bureaucrat) is in the formal structure of the bureaucracy, but all of them will be one preference in determine the behaviour and choices it takes.

\section{Methods}

Bureaucracy is a complex phenomenon that include for mere organizational dimensions and managerial technique, as observed through the positivistic paradigm but also includes social phenomena such as relations between social forces (ethnic and religious based) in accessing bureaucratic structures and policy. In this mainstream study, the obstacles for many researchers (including authors) is to take brave action to escape from the mainstream, including in explaining the phenomenon of relations in bureaucracy appropriately and not falling into deterministic perspectives.

Therefore, interpretive paradigm (approach) based on the method of phenomenology becomes the choice that researchers apply in designing and conducting research related to relation's theme between ethnic and religious groups in bureaucracy and its representational efforts. Researchers trying to understand perspectives to informers' understanding of representation as bureaucratic realities. Therefore, subjective action of political actors and bureaucracy as informer's experience and perspectives are not to be judged right or wrong but need to be interpreted in depth. It means, the considerations of political actors, 
bureaucracy and social context (inter-ethnic relation and religious with all the issues) become important considerations in the overall analysis.

In this position exactly, the researcher does constructs the representational reality in bureaucracy as suggested by Denzin and Lincoln (2009) and Neuman (2013). Nevertheless, the meaning generated in the social action must be critically examined as well. This is because the nature of reality actually consists of multiple layers and ruled by basic hidden structure. The deeper layers of the structure is not producing direct and immediate surface appearance at the empirical level, but may be suppressing each other which create a complicate surface appearance of the empirical structure (Denzin and Lincoln, 2009; Neuman, 2013).

\section{Finding And Discussion}

\section{Representation Bureaucracy Practice in NTT}

Discussion about the practice of representational bureaucracy in the context of plural societies such as Indonesia (NTT) is important (strategically) both theoretically and praxis. As a region with various social compositions, mainly ethnic (Flores, Sumba, Timor, Rote, Sabu, Alor) and religions (Catholic, Protestant, Islam), the issue of balance in bureaucracy becomes socially and politically sensitive issues (Bau,1999; Sayrani,2017).

Related to this, in the New Order period, Gery van Klinken (2007) has shown that the establishment of a stronger and continuing identity in open conflicts in some regions of Indonesia such as West Kalimantan, Poso, North Maluku and Central Kalimantan shows that the reality of plurality "be pressed" repressively during the authoritarian regime and not-well managed, it becomes a counterproductive time bomb for the Indonesian nation itself. Therefore, Kymlicka (2002), for example, poses an important caveat that the greatest challenge (state) in current democracy (including Indonesia) is finding the exact moral and political answer to deal with the problem of diversity which is the potential increase of both disunity and demands between groups (in Sayrani, 2017)

To some extent, this reality is the implication of the strong practice and thought of public administration which is oriented in positivistic epistemology. Based on this epistemology, the main value to be pursued is the efficiency institutionalized in a meritocracy model which is then systematically assume that all aspects or dimensions are beyond "the rational zone" of the bureaucracy to be regarded as a pathology, including the reality of various social identity.

On this kind of situation exactly, the idea of representational bureaucracy becomes relevant. Based on non-positivitic epistemology, the representational bureaucracy which is promoted in this article is a claim idea to accuse the neutrality regime in interpreting diversity, and also encouraging productive interpretation of the reality of the diversity of social identity in study and bureaucratic practice recently.

Substantially, the essence of representational bureaucratic theory is the reflection of the diversity from the communities served and an ability of the bureaucracy to respond various interests from different groups of society in making public policy (Selden 1997). Thus, representational bureaucracy becomes a symbol of promoting equality of opportunity and justice (Deleon, 2005). Kingsley (2003) believes that bureaucracy can not be defined as "ideal type" 
Weber's allegedly unrealistic because it ignores the value aspect, belief, "irrationality" attached to human (bureaucrat). The bureaucracy can not be neutral but should represent the public it serve (in Sayrani, 2017).

Then, how's the condition of representation in the bureaucracy, especially in the bureaucratic structure in NTT. The practice of representation in the bureaucracy can be identified in the phenomenon which is Mosher (in Kim, 1990, Selden, 1995) called a passive representation (descriptive) that is a representative situation of various social group identities (including ethnicity and religion) in public organizations (bureaucracy). The level of representation is measured by appropriate proportionality of social composition with the composition in bureaucracy (structure / category). The high compatibility between social composition with composition in bureaucratic structures is considered as ideal condition of a democratic bureaucracy.

In the context of East Nusa Tenggara, symptomatic practice of representation is found even in a closed and informal scheme. In this scheme, the representation, especially the establish of descriptive representations showed the main tendency of the high level of religion-based representation (overrepresented) in the bureaucracy on the one hand, and the unrepresentation of ethnic groups in the bureaucracy (underrepresented) on the other side (Sayrani, 2017).

At the same time, the practice and tendency of representation in the developing bureaucracy in East Nusa Tenggara is not a static process but tends to change, mainly from the aspect of importance. In the New Order, the tendency of representational practices in the bureaucracy was built on the basis of more sociological-dimensional interests. Through the representation approach in the bureaucracy, the regime of stability which are carried by New Order government is strengthened through symbolic distribution between ethnic and religious groups in bureaucracy.

In contrast, the post-New Order shows the opposite side. Politically, political actors (regional heads) are generated through highly competitive political contestation with the broader political space of citizens. This encourages political actors to use various political resources including bureaucracy. The implications of representation in bureaucracies which is mobilized by sociological interests, should be documented as political power. It means, when representation is done, then it is not merely an effort to promote justice between groups or sociological dimensions, but also part of the capitalization and consolidation politically in the bureaucracy. 
Picture 2

Actor's Self-interest, Context and Capacity in Esthablishment of Bureucracy

Representation

\section{Context of the New}

Order

$\rightarrow$ Structure of centralized politics/stability of politics

$\rightarrow$ Bureucracy design : political stabilized instrument

\section{Encouraging Structure}

Representation Approach

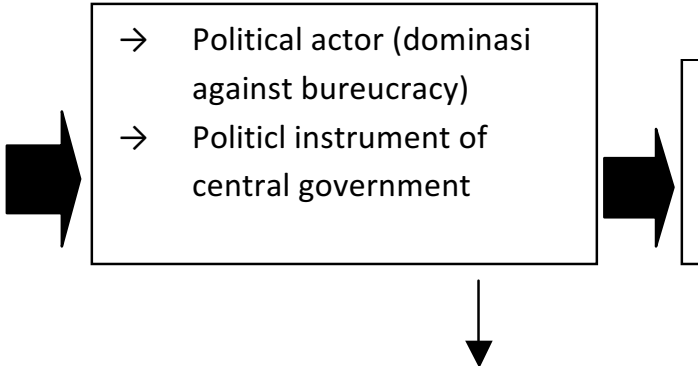

sociology orientation:

stabilization of bureucracy and

social $\rightarrow$ opened political structure

$\rightarrow$ bureucracy design : professional instrument but depends on local governor

\section{Context after the New Order}

(Local Election)

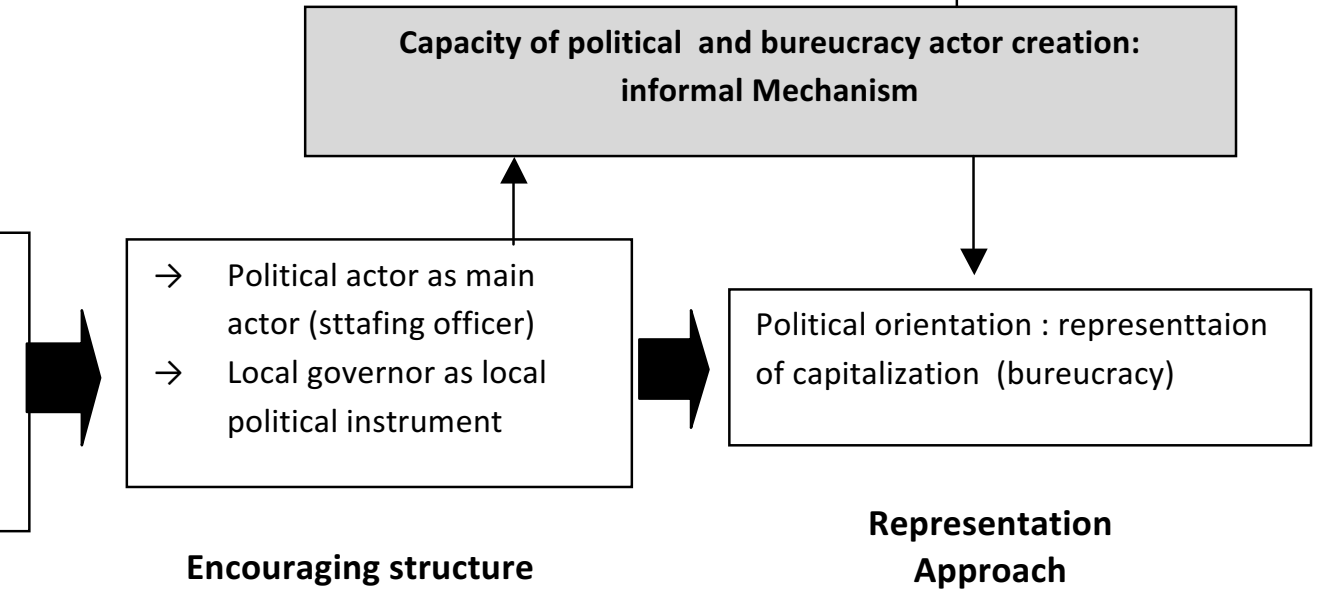

Source : Sayrani (2017)

These two tendencies tend to be interconnected yet with different intensities depending on the context. Therefore, these two tendencies are resulting in variant of representation in the bureaucracy in NTT that are objective representation, subjective representation and also non-representation with objectively neutral and political variants. 


\section{Picture 3}

The Variant of Representation Practice in Bureaucracy

The Government of NTT Province

\section{Objective}

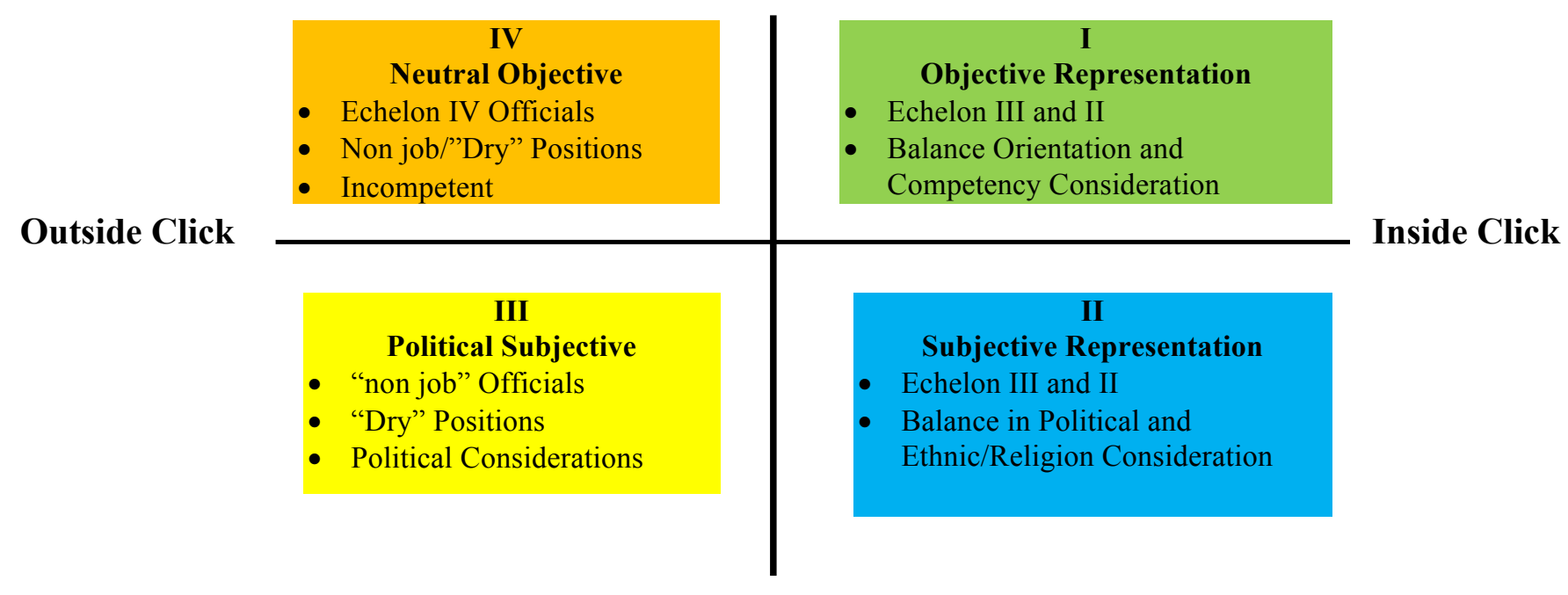

Subjective

Source: Sayrani (2017)

The practice of repesentation in NTT's bureaucracy shows the main limitations related with the attractiveness between the form of objective representation and subjective representation. Informal (subjective) representation which is completely focus on political considerations for ethnic / religious balance in bureaucracy has a vulnerability to shift into a non-representation subjective which an official is placed in a certain position as part of bureaucratic politicization. Indeed, it means that the practice of representation has an opportunity to be "hijacked" politically for political pragmatic interest.

This vulnerability is possible, especially driven by political contestation that tends to increase as the direct implications of local elections. In this situation, the political commitment of political actors (heads of regions) become determinant variable that is difficult to be predicted and controlled because of the attitude of political actors can be pragmatic in the political constellation.

On the other hand, the behavior of bureaucratic actors can also be very pragmatic to engage in practical politics by utilizing the bureaucratic and social resources, that they have in political contestation. This condition indicates that the practice of representation in the NTT's bureaucracy still leaves a gap, that is the unavailability of "safety valve" which can limit shift of subjective representation to the non subjective representation situation.

The dynamics of representational practices in NTT's bureaucracy in various variations and contexts point to one thing that within the context of (society) NTT, the presence of the state (bureaucracy) becomes important for society at all social layers. As Tedey (2015) said states (bureaucracy) have position as social structures establishment, which is all social 
component which depends on their access to the state (bureaucracy). Become a bureaucrat then a bureaucratic official is a means to access direct state resources that will be used to sustain the social and even political life of local political actors. In other words, when nonstate resources are not adequately available, the state (bureaucracy) and its resources become the main arena of contestation among social groups (Sayrani, 2017).

Regardless of the dynamism and limitation of representational practices in NTT's bureaucracy recently, the practice of representation in bureaucracy, especially based on objective representation, becomes relevant in plural societies such as NTT and Indonesia in general. Relevance is mainly related to the dimension of justice in a different perspective with justice based on the meritocracy regime.

The meritocracy system is basically built on the principle that bureaucracy (officials) is an equal open for all groups or equal treatment for all groups including ethnic / religious, meaning that anyone who has the ability to earn profit (or hold an official bureaucratic position). At the same time, meritocracy also emphasizes equality of fair opportunity through an open mechanism that allows everyone to access the position (bureaucracy).

Thus, justice in the perspective of meritocracy is justice based on the assumption that when the bureaucracy is able to recruit and promote a person based on his ability and through a fair mechanism, then justice in the bureaucracy has been achieved. This situation, by John Rawls referred to as liberal equality.

The weakness of this perspective is the absence of a strong guarantee of protection and implementation of equal rights for all people because of the distribution is only based on talents and abilities which are never equal, especially between different social groups. If then the ability becomes the main standard, then this will only create inequality, especially between strong groups with weak groups.

This kind of weakness that is the representational bureaucratic approach tries to overcome. In this mechanism, there is an effort to integrate the principle of "equally open" which points to a fair opportunity for all people and combined with the diferent principle which is in the recognition of the weak group to access the bureaucracy. With the inclusion of the diferent principle, there is an opportunity for a better talented society to gain greater benefits, but it provides equal opportunities for the less fortunate to access the bureaucracy at the same time. This situation which is Rawls referred as democratic similarity.

This idea implies that justice does not necessarily mean treating everyone equally regardless of objective differences among the relevant individuals (group). Therefore, representational bureaucracy is able to encourage the spirit of equality without fall into naive equality demands.

\section{Representation In Duality Structure}

The practice of representation in bureaucracy based on informal mechanisms that is developed in NTT's bureaucracy shows that bureaucratic bureaucracy processes in the framework of structural duality. In this scheme, the bureaucracy works through both objective and subjective processes mutually. Through the objectification process, the bureaucratic structure will determine behavior of political actors and bureaucracies to work in a formal system (formal system). Nevertheless, political actors and bureaucracies themselves are not passive actors who are easily denominated by formal objectification processes. They 
have capacity to recreate the formal structure of the bureaucracy through a subjective process that result in an informal system in the bureaucracy (Sayrani, 2017).

Picture 4

Representation in Duality Structure

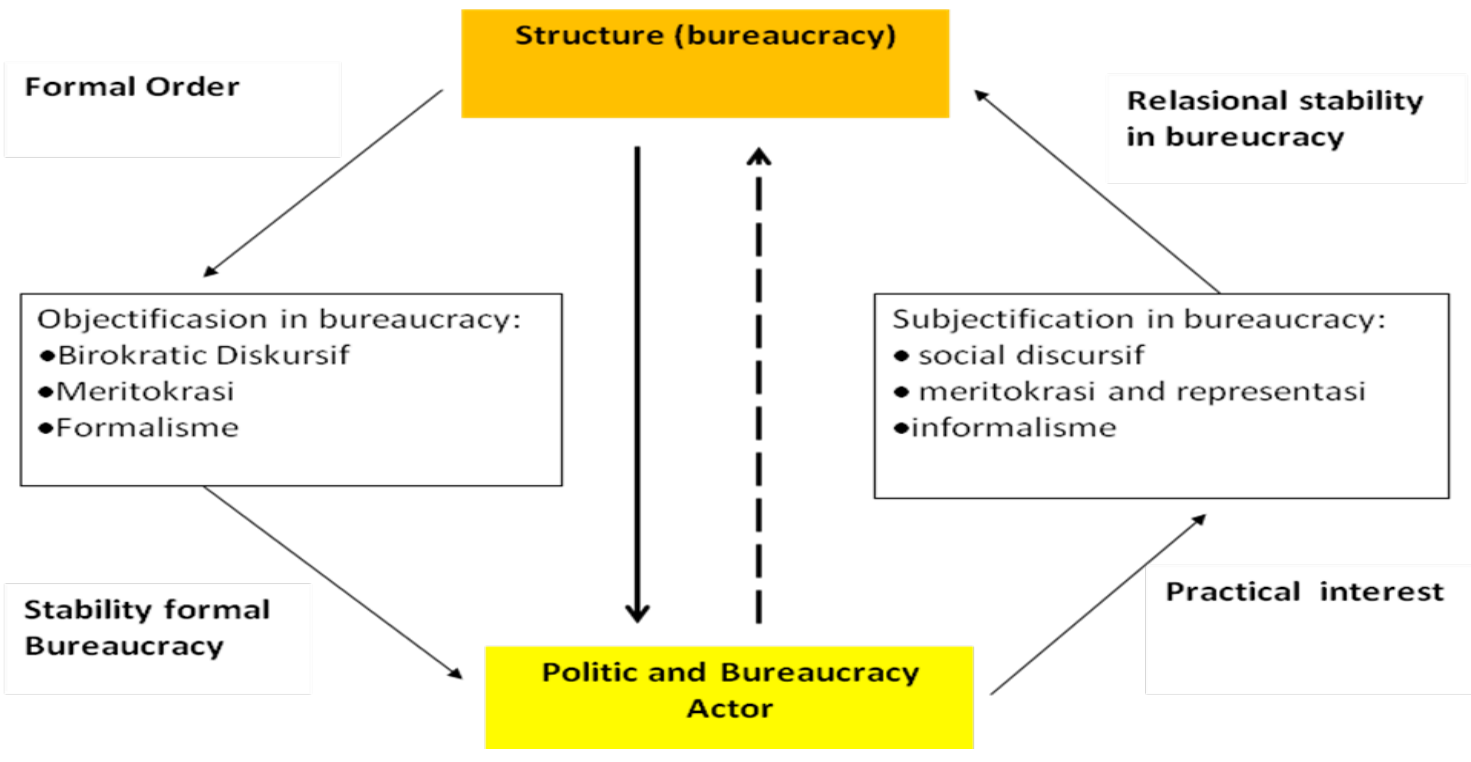

Sumber : Sayrani (2017)

This scheme shows that the formal system of bureaucracy, the behavior of bureaucratic actors (including head of region) is aimed at formal awareness and compliance with the bureaucracy's values and working procedures, which are point to internalization of knowledge related to formal bureaucracy (formal rules, formal orientation) and bureaucratic actions. This condition is called objectification in the bureaucracy.

This formal compliance is generated through an internalization process called the objectification process. In this mechanism, there is a bureaucratic discursive process which in formal knowledge of bureaucracy is continuously constructed by a formal structural order, both within its own hierarchical bureaucracy which is socialized through various formal acts such as training, education to daily conversations about the formal rules of the bureaucracy.

Furthermore, objectification is also constructed through the application of a mechanism of work based on meritocracy. Various stages in the bureaucracy starting from recruitment, placement, promotion process and various stages of bureaucratic management are directed to formal standards of bureaucracy in accordance with various existing employment regulations. This stages process is called formalism which refers to the standardization of all bureaucratic behavior according to the formal framework of the bureaucracy. The end of all these processes is stabilization of the formal mechanisms in bureaucracy which is all formal frameworks are institutionalized in bureaucracy (actors, values and work).

However, the objectification process that leads to the institutionalization of the formal bureaucracy, does not necessarily limit the bureaucratic and political actors to create their interests. When the formal structure of the bureaucracy is not sufficient enough to manage 
this proportionally, then political actors (heads of regions) and bureaucrats (actor behavior) then develop other mechanisms through a process of subjectification in bureaucracy.

As the process of objectification, then the subjective in the bureaucracy by the actor is also done through several mechanisms. Representation is primarily constructed through social discourse (politics) that takes place in the public arena as well as internal bureaucracy about the balance between ethnic / religious groups in access and distribution in the bureaucracy. Position, distribution, inequality between social groups in the bureaucracy to inter-regional development situations continues to be a daily conversation up to a more formal areas of all actors, which are bureaucratic, political and social actors on various opportunities. This conversation is the discourse that create collective subject consciousness from each ethnic / religious group as well as NTT's people in general that has developed since NTT was established.

This situation is managed by developing informal mechanisms with subjective measures, especially by regional heads to conduct ethnic and religious-based distributions in bureaucracy by integrating them into formal bureaucratic practices. The options that are then developed are to impose the formal mechanisms of bureaucracy with consideration of ethnic / religious balance in the distribution of bureaucrats in official positions.

This subjective process of informal bureaucracy becomes another mechanism to address the needs of local (social, bureaucratic and political) bureaucracies that lead to the maintenance of social stability in the bureaucracy and the public of NTT in general. Representation is done because through this mechanism allows effective conflict management to be done. The mobilization of communal bases such as ethnicity and religion is done in private and when it is done in a closed manner, the confrontation between groups in both bureaucracy and at the public level will be under control. This is not solely due to the ability of bureaucratic and political actors to exercise direct control but precisely because of the disguised identity mobilization that has never been opened objectively but subjectively managed. This causes the demands of actors in bureaucracy and external are also vagues and informal as well. With this strategy, practical shocks (protests, criticisms) both internally and public can be controlled politically and bureaucratically. This is particularly characterized by the easing of prejudices, jealousy, conflicts (closed) among ethnic / religious groups in the bureaucracy that is concerned may hamper the process and performance of the bureaucracy.

\section{Conclusion}

The important idea of this article is that in the context of plural society, the bureaucratic theory based on positivistic epistemology that decrease in bureaucratic explanation as a formal and rational process (meritocracy) is not sufficient enough to adequately explain and understand bureaucratic dynamics. Interaction in the bureaucracy is not merely limited to formal interaction but there is developing in an informal interaction that involve in social preference of individual bureaucrats.

This situation indicates that: 1) actors (bureaucracy and politics) have the creativity to deal with the determination of objective structures by building subjective frameworks that allow their practical interests to be accommodated in formal structures. 2) bureaucracy is an entity that is supported by two linked structures / systems which are bureaucratic formal 
structures / systems, and informal systems that is mutually interact and not in dichotomous positions (structural dualities). 3) representation practice is the production of political actors power and bureaucracies that turn out to be scattered in the sense that they are not centralized and run hierarchically by actors at higher levels (central government to local government and regional heads to bureaucrats). The practice of representation in bureaucracy shows that the character of power which is operating in the bureaucracy tends to spread, not hierarchical and productive.

\section{References}

Alkadry, Mohamad G. (2007). Democratic Administration in a Multicultural Environment. In Democracy and Public Administration. Edited by Richard C. Box. M.E. Sharpe. New York

Bau, Yanuarius Koli. (1999). Negara, Etnisitas, dan Sektor Informal : Kasus Kupang Nusa Tenggara Timur. Disertasi pada Jurusan Sosiologi Universitas Gadjah Mada, Yogyakarta

Buchari, Sri Astuti. (2014). Kebangkitan Etnis Menuju Politik Identitas. Yayasan Pustaka Obor Indonesia, Jakarta

Ballard, Velma J. (2015). Gender and Representative Bureaucracy: The Career Progression of Women Managers in Male Dominated Occupations in State Goverment. Disertasi, The Virginia University, Virginia

Clark, Nita, (2015). Representative Bureaucracy and The Indirext Effects of Subtantive CoWorker Representation. Disertasi, The Texas University, Arlington

Deleon, Linda. (2005). Public Management, Democracy, and Politics. in The Oxford Hand Book of Public Management. Edited by Erwan Ferlie, Laurence E. Lynn and Christpher Pollit. Oxford University Press

Denzin, Norman K., \& Yvonna S Lincoln (Editors).(2009). Handbook of Qualitative Research. Pustaka Pelajar, Yogyakarta

Evans, James W. (1974). Defening Representative Bureaucracy. Public Administration Review, Vol. 34, No.6. Dipublikasikan the American Society for Public Administration

Frederickson, H. George. (2003). Administrasi Negara Baru, cetakan kelima, LP3ES, Jakarta

Goode, Shelton J. (2000). Representative Bureaucracy: African American Mayors and Employess in Municipal Goverment. Disertasi, The Alabama University, Alabama

Grissom, J.A, Crotty, J.N \& Crotty, S.A. (2009). Race, Region and Representative Bureaucracy. Public Administration Review, 911-919

Kymlicka, Will. ( 2002). Kewargaan Multikultural. LP3ES, Jakarta

Hamilton, Mary R. (2003). Democracy and Public Service. In Democracy and Public Administration. Edited by Richard C. Box. M.E. Sharpe, New York

Kim, Pan Suk. (1990). Toward Representive Bureaucracy : A Trend Analysis of The Korean Civil Service. Disertasi, The American University, Washington 
Kingsley, J Donald. (2003). Representative Bureaucracy. In Represensentative Bureaucracy : Classic Readings and Continuing Controversies, edited by Julie A. Dolan and David H. Rosenbloom. M.E. Sharpe, Armonk, New York

Klinken, Gerry Van. (2007). Perang Kota Kecil : Kekerasan Komunal dan Demokratisasi di Indonesia. KITLV dan Yayasan Obor Indonesia, Jakarta

Kennedy, Brandy. (2009). Reassessing Representive Bureaucracy : An Exploratory Analysis Using Role Perception. Disertasi, The Oklahoma University, Oklahoma

Lewis, Willian Gilbert. (1988). Toward Representive Bureaucracy : An Assesment of Black Representation in Police Bureaucracies. Disertasi, The New York University, New York Neuman, W Lawrence. (2013). Metodologi Penelitian Sosial: Pendekatan Kualitatif dan Kuantitatif. Edisi ke tujuh. Indeks, Jakarta

Mohamed, Ahmad Martadha. (2004). Representive Bureaucracy and Policy Preferences : Linking Descriptive Representation and Potential for Subtantive Represention in The Malaysian Bureaucracy. Disertasi, The Southem Illinois University, Carbondale

Maroney, Hewins Berbara., \& Ethel Williams. (2007). Teaching Diversity in Public Administration : A Missing Component? Journal of Public Affairs Education, Vol,13, No.1. http://www.jstor.org/stable/40215767

Major, Kristen Norman. (2011). Balancing the Four Es: or Can We Achieve Equity for social Equity in Public Administration. National Association of Public Affairs and Admnistration (NASPAA). Vol.17, No.2. http://www.jstor.org

Selden, Sally Coleman. (1995). Representative Bureaucracy : Examining the Potential for Administrative Responsiviness in The Bureucratic State. Disertasi, The Georgia University, Georgia

Selden, Sally Coleman.(1997). Representative Bureauracy : Examining the lingkage Between Passive and Active Representation in the Farmes Home Administration. American Review of Public Administration. Vol.27 No 1, March 1997. Sage Publication,Inc.

Sjaf, Sofian. (2014). Politik Etnik: Dinamika Politik Lokal di Kendari. Yayasan Obor Indonesia, Jakarta

Sayrani, Laurensius Petrus. (2017). Dinamika Representasi Dalam Birokrasi Pemerintahan Di Provinsi Nusa Tenggara Timur. Disertasi pada Program Doktor Manajemen dan Kebijakan Publik, Fakultas Ilmu Sosial dan Politik, Universitas Gadjah Mada, Yogyakarta.

Tidey, Sylvia. (2016). Sebuah Kota yang Terbelah : Perkembangan dari Segmentasi Berbasis Etnik ke Berbasis Kelas di Kupang, Timor Barat. Dalam In Search of Middle Indonesia : Kelas Menengah di Kota-Kota Menengah. Gerry van Klinken dan Ward Berenschot (Editor). KITLV dan Yayasan Obor Indonesia, Jakarta

Yakoop, Mohamad Rizal. (2013). Etnisitas sebagai Instrumen Politik dan Keamanan di Kalimantan Barat Pasca Rezim Orde Baru. Jurnal Ilmu Sosial dan Politik, Volume 17, Nomor 1. Fakultas Ilmu Sosial dan Politik Universitas Gadjah Mada 